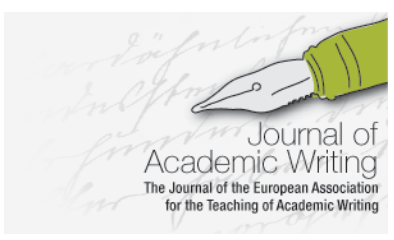

Journal of Academic Writing Vol. 8 No 1 Summer 2018, pages 113-116 http://dx.doi.org/10.18552/joaw.v8i1.491

\title{
Review of Write No Matter What: Advice for Academics
}

\author{
Steven E. Gump \\ Princeton University, USA
}

\begin{abstract}
Jensen, Joli. (2017) Write No Matter What: Advice for Academics. Chicago: University of Chicago Press, pp. 178, \$15.00, £11.50, €13.50, ISBN 9780226461700
\end{abstract}

Year in, year out, scholarly and trade presses alike release new books on academic writing for publication, leading Kristin Solli recently to ask, 'Do we need another book offering advice on academic writing?' (2017: 59). These works typically either focus on writing for publication within a particular field or discipline (e.g. Donovan 2017, Egbert and Sanden 2015, Saver 2011) or present the impression of being more broadly applicable, while still being grounded in the author's (or authors') relatively narrow experiences (e.g. Jalongo and Saracho 2016, Johnson 2011, Rocco and Hatcher 2011). Helen Sword, approaching the situation empirically, assesses authors of both types of works: 'Successful academics who have never been formally trained as writers themselves are often eager to relay the "tricks of the trade" to younger colleagues, without realizing that what worked for them might not necessarily work for everyone' (2017: 75). Oblivious of the genre to which they belong, the least helpful books of this ilk exist in an imaginary vacuum.

Joli Jensen's Write No Matter What: Advice for Academics avoids the usual complications. Part of the Chicago Guides to Writing, Editing, and Publishing series, Write No Matter What focuses not on mastering the technicalities of academic writing - take your pick among the extant titles on that topic, broad or specific to your field - but on understanding and successfully navigating the contexts that complicate the academic writing process. Across twenty-eight brief chapters (averaging just five pages), Jensen upends the excuses academics invoke to explain why their writing languishes. (Coincidentally, Belcher (2009) presents twenty-eight obstacles to writing not as myths but to demonstrate that such impediments are numerous, commonplace, and not to be feared.) But Jensen is not self-righteous. Instead, she is one of us, and she understands the challenges we face. Her goal with this book is not to remove the barriers to productive writing but to help us overcome them by, in part, acknowledging the emotional and psychological dimensions of writing. Her reassuring, inspiring voice exudes empathy and encouragement, channeling Cameron (2004), Lamott (1994), Sword (2017), and other gurus who also recognize that writing is 'hard and sometimes scary work' (72).

As professor of communication at the University of Tulsa (Oklahoma, USA), Jensen also directs the Henneke Faculty Writing Program and thus embodies the harried and time-deprived scholar-administrator. Insights come from her own experiences as well as from years of leading writing workshops and one-on-one writing consultations with scholars. In the acknowledgments, she notes that parts of the book originated as a handout called 'Myths We Stall By' (ix). Other material presented in Write No Matter What debuted in Vitae, the online career website affiliated with the Chronicle of Higher Education. The book is no mere collection of previously published postings but rather a thoughtfully organized approach stemming from a simple premise and involving three 'taming techniques.'

Jensen presents her key premise without fanfare in the preface and in the conclusion, with the intervening chapters serving to underscore the idea: 'Productive writing requires frequent, lowstress encounters with an enjoyable project' (149). Every adjective in that statement is equally 
important - productive, frequent, low-stress, and enjoyable - and Jensen explains and elaborates with examples and evidence. She organizes the chapters into five parts: a contextual introduction, emotional and organizational tools, writing myths debunked, 'maintaining momentum,' and 'building writing support.' An afterword focuses on 'scholarly journalism' (that is, writing for the broader public), possibly foreshadowing a dimension Jensen will further explore in a future work. (In the meantime, I encourage readers interested in the topic to procure a copy of Stein and Daniels (2017), from the same excellent University of Chicago Press series.)

Active writing gives the text immediacy and imbues sentences with remarkable profundity: 'where we spend our time is how we spend our lives' (25); 'scholarly work is . . what we do, not who we are' (61); 'writing well is thinking well, because it requires recognizing and eliminating weaknesses, contradictions, elisions, gaps, and misunderstandings' (92). Wisdom permeates the pages. If you're an underliner or a highlighter - or an ornamenter of marginal exclamation points, asterisks, or other embellishments of textual engagement - you'll not be able to make it through a single chapter without marking something that resonates, inspires, or even surprises.

With respect to frequency, Jensen encourages scholars, à la Boice (1990), Bolker (1998), and Valian (1977), to write every day for at least fifteen minutes. This strategy, in fact, is one of her three taming techniques, and she argues that scholars can and should take responsibility for how they prioritize at least some of their time: 'We are not horses straining to pull carts loaded with other people's needs and demands. We get to decide how and when to load our own cart, each and every day' (33). Asking for fifteen minutes daily for work we should be prioritizing anyway is not unreasonable. Another taming technique, borrowed from David Sternberg (1981), is to create what Jensen calls a 'project box': a receptacle, ideally portable, wherein you collect all the materials you need for a project - reading notes, outlines, transcripts, photocopies or scans of primary sources, and so on. She is, in short, encouraging us to get organized, since efficiency declines when one wastes time looking for materials - or when one's materials become scattered between or among workspaces. Granted, the project box for individuals who have digitized their lives and taken vows of paperlessness may exist on a computer, on a flash drive, or in the cloud; the key is to keep everything together and easily accessible whenever time to engage with the project arises.

The final - and 'most crucial and helpful' (19) - of Jensen's taming techniques, also borrowed from Sternberg (1981), is to keep a 'ventilation file': a place where you record any challenges or difficulties pertaining to writing, either in general or specific to a particular writing project. Think of it as therapy: a way to relieve yourself of the things that most frustrate or bother or annoy. Think of it, also, as a way to unburden yourself when you get stuck. John McPhee offers a similar suggestion for writers who are 'blocked, frustrated, in despair': 'You write, "Dear Mother." And then you tell your mother about the block, the frustration, the ineptitude, the despair. . . Y You whine. You whimper. You outline your problem' (2013: 32), and then you start writing what you were thinking about your project. Ultimately, you go back and delete 'Dear Mother' - plus all the whining and whimpering - and, voilà, you have a workable first draft. Jensen's goal with the ventilation file is not necessarily to yield a working draft but to provide a dumping ground or processing space for anything that comes between you and your writing: 'our writing demons stop deflecting our writing when we find ways to converse with them rather than try to ignore or fight against them' (45, original emphasis).

Myths Jensen debunks involve perfectionism, fears of hostile readers, the impostor syndrome and feelings of inadequacy, and what she calls the 'cleared-deck fantasy': 'the mistaken belief that we should take care of all our other obligations before we can really get going on our writing' (56). This passage exemplifies the positivity of her approach and the way she charges readers to reframe their attitudes toward scholarly writing around her key premise:

Our scholarly work is not just one more unwelcome obligation. It is a voluntary commitment - what we need to do to be happy and successful in our chosen field. Scholarly writing should be an activity we respect and believe in. It is not just 'one more thing.' It is the main thing in our professional lives. It can be a pleasant, rewarding thing 
- once we learn how to give ourselves frequent low-stress, high-reward encounters in a supportive environment with a project we care about. (59, original emphasis)

The surprises in Write No Matter What are of the good sort. In a revelatory move, Jensen gives readers permission to abandon a seriously stalled writing project they've come to loathe: 'sometimes letting go is the only way to make room for something better' (113). She presents the metaphor of a 'buddy log' (a smaller log used to help a larger log burn better) to describe 'back-burner' projects that can help motivate 'front-burner' projects when productive distraction is needed (117). (Christine Tulley notes that such an approach, which she calls 'toggling or shuttling between projects' (2018: 26), can help writers remain productive in even the smallest fragments of time.) Jensen encourages us to talk with others about their writing projects and to listen for 'the lilt': 'Almost everyone's voice gets more energetic or musical when they are describing something that engages them. Almost everyone's voice gets flat and mechanical when describing something they "should" like but really don't' (78). And in what I feel is the largest coup, Jensen argues against joining 'content-critique' writing groups. Instead, she suggests creating special writing groups that focus on the writing process - and provide space for airing the emotions and baggage that come with scholarly writing. "What academic writers need (and rarely get),' she writes, 'is support for the writing process itself. We need to help each other actually get our writing done' (137). Amen.

Delightful in its straightforwardness and refreshing in its candor, Write No Matter What promises to inspire and energize those who take its suggestions seriously. Jensen's style makes writing seem effortless - even though she knows it is anything but. The attention to which Jensen gives the craft of her own writing underscores her idea that we can always become more effective, more productive, and more personally satisfied as writers. 'The ethic of craftsmanship involves a willingness to focus, directly and methodically, on what we don't yet know so that we can learn how to work with ever-increasing skill,' she explains in an early chapter (10). Write No Matter What is brimming with tips, strategies, and suggestions to help readers refocus their energies, set and stick to their priorities, and ultimately find pleasure in sharing their ideas with others.

Reading this book should help beginning and seasoned academic writers alike learn how to improve both their craft and their relationships with their writing processes. Even readers for whom English is not their native language should find Jensen's direct, conversational approach appealing, not intimidating. Prolific, confident scholars who are completely organized, never running behind schedule, and otherwise always in control of their lives may have the least to learn. In short, and in affirmative response to Solli's query, Jensen's Write No Matter What is another book offering advice on academic writing that, yes, we actually need. 


\section{References}

Belcher, W. L. (2009) Writing Your Journal Article in Twelve Weeks: A Guide to Academic Publishing Success. Thousand Oaks, CA: SAGE

Boice, R. (1990) Professors as Writers: A Self-Help Guide to Productive Writing. Stillwater, OK: New Forums

Bolker, J. (1998) Writing Your Dissertation in Fifteen Minutes a Day: A Guide to Starting, Revising, and Finishing Your Doctoral Thesis. New York, NY: Holt

Cameron, J. (2004) The Sound of Paper: Starting from Scratch. New York, NY: Tarcher

Donovan, S. K. (2017) Writing for Earth Scientists: 52 Lessons in Academic Publishing. Chichester, UK: Wiley Blackwell

Egbert, J., and Sanden, S. (2015) Writing Education Research: Guidelines for Publishable Scholarship. London, UK: Routledge

Jalongo, M. R., and Saracho, O. N. (2016) Writing for Publication: Transitions and Tools That Support Scholars' Success. Cham, Switzerland: Springer

Johnson, N. F. (2011) Publishing from Your PhD: Negotiating a Crowded Jungle. Farnham, UK: Gower

Lamott, A. (1994) Bird by Bird: Advice on Writing and Life. New York, NY: Random House

McPhee, J. (2013) 'Draft No. 4'. The New Yorker 29 April, 32-38

Rocco, T. S., and Hatcher, T. (eds.) (2011) The Handbook of Scholarly Writing and Publishing. San Francisco, CA: Jossey-Bass

Saver, C. (2011) Anatomy of Writing for Publication for Nurses. Indianapolis, IN: Sigma Theta Tau International

Solli, K. (2017) 'Review of Writing Your Master's Thesis: From A to Zen.' Journal of Academic Writing 7 (1), 59-62

Stein, A., and Daniels, J. (2017) Going Public: A Guide for Social Scientists. Chicago, IL: University of Chicago Press

Sternberg, D. (1981) How to Complete and Survive a Doctoral Dissertation. New York, NY: St. Martin's

Sword, H. (2017) Air \& Light \& Time \& Space: How Successful Academics Write. Cambridge, MA: Harvard University Press

Tulley, C. E. (2018) How Writing Faculty Write: Strategies for Process, Product, and Productivity. Logan, UT: Utah State University Press

Valian, V. (1977) 'Learning to Work.' In Working It Out: 23 Woman Writers, Artists, Scientists, and Scholars Talk about Their Lives and Work, ed. by Ruddick, S., and Daniels, P. New York, NY: Pantheon, 162-78 